\title{
Olavo Bilac e a experiência da República no Brasil
}

\section{Thiago Roza Montilha*}

Resumo: O presente artigo pretende analisar as impressões e representações veiculadas por Olavo Bilac acerca da República brasileira tendo como recorte cronológico os anos compreendidos entre 1897 e 1908 e a cidade do Rio de Janeiro como o espaço privilegiado em tal análise. Neste trabalho pretendemos não apenas captar as diferentes representações veiculadas pelo poeta-jornalista Olavo Bilac acerca da República brasileira, mas também analisar e determinar algumas das muitas razões que o levaram a construir a sua complexa visão sobre o nosso primeiro sistema de governo republicano.

Palavras-chave: Bilac; República; Intelectuais.

Abstract: This article aims to analyze the impressions and representations published by the chronicler Olavo Bilac at the press of his time and about the brazilian Republic. The period focused it that is between 1897 and 1908 and the privileged space in our analyze is the city of Rio de Janeiro. Here, we want not just capturing the different representations published by Olavo Bilac about the brazilian Republic, but also to analyze and determine some of the several reasons that led him to construct his complex view about our first government republican system.

Keywords: Bilac; Republic; Intellectuals.

Graduando do curso de licenciatura em História pela UERJ - FFP e bolsista CNPQ do projeto "Sonhos de um Brasil letrado e saudável: os intelectuais em busca de um Povo" da professora doutora Magali Engel. 
Os anos que compuseram o último quartel do século XIX e as primeiras décadas do século XX foram bastante movimentados e trouxeram o desencadeamento de significativas modificações sociais, econômicas, políticas e culturais para a sociedade brasileira da época, ainda que possamos perceber algumas de maneira mais destacada e outras de modo mais silencioso. Contudo, a proclamação da República em novembro de 1889, talvez seja o movimento mais abrupto deste contexto histórico que nos revela de modo inédito a instalação de um regime eletivo e laico no Brasil que trouxe no decorrer de sua consolidação, a afirmação de um novo arranjo administrativo e institucional com a chamada "política dos governadores", o desfazimento das estreitas relações entre Estado e Igreja comuns ao Império de Pedro II, a complexificação dos canais de comunicação estabelecidos com a sociedade civil, agora teoricamente composta não por súditos, mas por cidadãos, entre outras mais.

A proclamação ocorrida em 15 de novembro de 1889, apesar de um tanto repentina, se deu em meio ao processo de crise do regime imperial, corrente desde meados do último quartel do século XIX. Tal crise nos revela o declínio do Império através do desgaste das relações que este mantinha com importantes "atores", grupos sociais e instituições daquele contexto e fulcrais à manutenção do status quo imperial. Como exemplo, vale lembrar alguns movimentos que marcaram o ocaso do Segundo Reinado tal como a oposição realizada pelo emergente movimento republicano, sobretudo aquele 
encabeçado pelo PRP, o desgaste com a Igreja católica, os crescentes conflitos com o Exército brasileiro devido ao descaso da Coroa para com a instituição militar ao longo da segunda metade dos Oitocentos, e a militância de oposição por parte de intelectuais brasileiros, sobretudo aqueles que integraram a famosa "geração de 1870" (ALONSO, 2002), contra a lentidão da monarquia na realização das desejadas e variadas reformas de modernização social de que o Brasil supostamente tanto necessitava por ser um país notoriamente atrasado em relação ao mundo europeu de plena estabilidade política, progresso econômico e desenvolvimento social.

Embora a causa republicana tenha sido abraçada por grupos civis e militares, a República se fez no Brasil sob a liderança dos segundos e sem qualquer apoio da população comum que assistiu alheia e desconfiadamente aos movimentos daquele golpe republicano do dia 15 de novembro. Como causa para essa nãoadesão da população local, sobretudo dos setores populares, ao nascente regime republicano, José Murilo de Carvalho (CARVALHO, 1987) aponta a enorme popularidade alcançada pela monarquia naquele contexto pós-Abolição ${ }^{1}$, embora também tenha ressaltado um voluntário distanciamento de tais segmentos populares, segundo o próprio, em nada afeitos à participação política

\footnotetext{
${ }^{1}$ Nas palavras do autor: "A euforia inicial, a sensação de que se abriam caminhos novos de participação parecem não ter atingido este setor da população. Eu diria mesmo que a Monarquia caiu quando atingia o seu auge de popularidade entre esta gente, em parte como consequência da abolição da escravidão." (CARVALHO, 1987, p.29)
} 
através dos canais oficiais estabelecidos pelo regime. Por outro lado, podemos também destacar os estudos de Maria Tereza Chavez de Mello (MELLO, 2007) que, embora convirjam com José Murilo a respeito da ausência de apoio popular ao golpe de 1889, num sentido divergente procuram enfatizar como bastante presente em nossa população tanto um notório sentimento de indiferença quanto ao sistema de governo que a regeria, a despeito da simpatia pela monarquia que reconhece como existente naquele contexto, quanto a percepção de que a República era uma transformação "inevitável" historicamente (MELLO, 2007, p.231), sendo tal "sensação" devida principalmente à difusão das culturas científica e democrática pelo Brasil.

De todo modo, é fundamental percebemos que tal perspectiva que trata do golpe de 15 de novembro como marcado pela ausência de apoio popular é ponto pacífico à historiografia que trata do tema, embora ainda existam divergências, por exemplo, quanto à natureza das reações da população comum perante a deposição da monarquia de Pedro II. E já quanto o processo de afirmação desta República que nasceu no Brasil, segundo Renato Lessa, sem qualquer projeto por parte dos militares que definisse a sua "rotina" institucional e administrativa, vale destacar que, tanto o próprio Lessa (LESSA, 2001) quanto José Murilo de Carvalho (CARVALHO, 1987), percebem acertadamente que os "moldes" que definiram o "funcionamento" daquela que se chamaria a "República Oligárquica", apenas fizeram fortalecer o afastamento popular dos canais oficiais de participação política, afinal, para além daquelas parcelas da 
população já excluídas da cidadania política pelas exigências presentes na Constituição de 1891, aquelas aptas ao voto escolheriam também em bom número não ir às urnas, ato este visto como potencialmente perigoso já que, durante a Primeira República, apenas recrudesceriam as violências praticadas por capoeiras a mando de oligarcas e coronéis, as fraudes eleitorais, a compra de votos, dentre outros abusos e excessos.

Nesse sentido, a República brasileira, ainda que tenha sido inaugurada sob os elogios dos adeptos da participação democrática, na verdade acabou se revelando como altamente excludente em termos de participação eleitoral, como bastante truculenta e insensível em sua sistemática repressão às classes populares daqui então vistas como "classes perigosas", e como "controlada" pelas pretensões políticas descentralizadoras das oligarquias agroexportadoras que passaram, com a caída do Império, à posição de hegemonia naquela sociedade de virada de século.

É importante que seja destacado que neste artigo pretendemos abordar e analisar justamente a perspectiva de um dos mais importantes intelectuais nacionais do período da Primeira República a respeito do inédito regime republicano brasileiro e que seguramente inseria-se num extenso grupo de homens de letras que não somente se entusiasmou, mas que também militou em prol da queda da Coroa e da ascensão da República no Brasil, percebendo ambas as "frentes" como fundamentais à entrada do país na era de modernidade que se abria no mundo ocidental desde meados do século XIX. Assim, enquanto intelectual detentor de privilegiado de 
posicionamento de classe em seu tempo, o multifacetado Olavo Bilac é o sujeito histórico enfocado em nosso trabalho que prima pela análise da perspectiva que possuía acerca da República no Brasil.

Em meio a diferentes recepções frente à inauguração do novo regime, recepções que foram do enorme entusiasmo de intelectuais como Coelho Neto, Olavo Bilac e Aníbal Falcão ao seu posterior desencantamento com os rumos que o mesmo tomou ao longo de sua consolidação enquanto sistema de governo altamente elitista e negligente perante as muitas problemáticas que tanto afetavam o país há séculos, podemos situar o poeta-jornalista Bilac como inserido nesta dinâmica histórica que inicialmente trouxe ventos de euforia à sociedade brasileira da época, sobretudo pela possibilidade de ampliação da participação política, mas que acabaram por dissipar-se com a afirmação do domínio oligárquico por todo o país, o que seguramente contribuiu bastante para a corrupção de grande parte das esferas de governo e das instituições republicanas oficiais. E nesse sentido, José Murilo de Carvalho fornece um interessante panorama a respeito da recepção/percepção de alguns grupos sociais, dentre eles parte da intelectualidade nacional, frente àquela proclamação da República que teve o seu encanto logo quebrado pelo autoritarismo de seus dois primeiros governos militares:

A expectativa inicial, despertada pela República, de maior participação, foi sendo assim sistematicamente frustrada. Desapontaram-se os intelectuais com as perseguições do governo Floriano; desapontaram-se os operários, sobretudo sua liderança socialista, com as dificuldades de se organizarem em partidos e de participarem do processo 
eleitoral; os jacobinos foram eliminados. [...] Quanto ao grosso da população, quase nenhum meio lhe restava de fazer ouvir sua voz, exceto o veículo limitado da imprensa. (CARVALHO, 1987, p. 37)

Assim, é referencial que tenhamos o posicionamento e a trajetória intelectual de Olavo Bilac bem como as suas variações ao longo do tempo como inseridos neste processo histórico, repleto de avanços e retrocessos, que serviu para inúmeras reflexões por parte deste autor que desde a sua juventude se mostrou como plenamente a favor da República no Brasil, e consequentemente, como contrário ao atrasado e autoritário regime imperial, embora Bilac jamais tenha deixado de exercer as inúmeras críticas que julgou merecidas àquela República que via como ainda em processo de aperfeiçoamento.

O nosso autor possuía suas origens nos setores médios da sociedade carioca de fim de século e conseguiu ainda jovem consagrar-se como o maior representante da poesia parnasiana nacional. Contudo, a trajetória intelectual do jornalista Olavo Bilac assumiu feições mais destacadas e perante um público ainda maior quando firmaram-se as suas contribuições para os grandes jornais da época, sobretudo a partir da segunda metade da década de 1890 quando substituiu Machado de Assis nas colunas dominicais da popular e consagradora ${ }^{2}$ Gazeta de Notícias e passou a publicar suas crônicas em outros importantes periódicos daquele contexto tais

\footnotetext{
${ }^{2}$ Segundo o próprio Olavo Bilac, "a Gazeta, naquele tempo, era a consagradora por excelência. Não era eu o único que a namorava; todos os da minha geração tinham a alma inflamada nessa mesma ânsia ambiciosa." (BILAC, 02/8/1903)
} 
como o Estado de São Paulo, A Bruxa (seu próprio empreendimento junto de Julião Machado), a luxuosa Kosmos, o Correio Republicano (órgão oficial do PRP), entre outros mais. Por outro lado, lembramos que a trajetória jornalística de nosso autor iluminou a nossa escolha quanto ao recorte cronológico deste trabalho, afinal, tendo em vista analisar as suas impressões sobre a República brasileira enfocando a sua carreira jornalística e exclusivamente a partir de seus escritos cronísticos, julgamos que o ano de 1897, como marco inicial, é basilar à nossa análise, pois nos traz Bilac em seu momento de plena consagração cultural, assumindo o lugar de Machado de Assis nas colunas da "Gazeta", o jornal mais importante da capital federal, e por outro lado, enquanto desfecho de nosso recorte, adotamos o ano de 1908 por nele encontrarmos o abandono de nosso autor das atividades jornalísticas de modo geral. Daí em diante, Bilac se dedicaria à militância nacionalista através de organizações civis como a Liga de Defesa Nacional e em prol da massificação da instrução popular, da expansão do saneamento pelo país, da reorganização das forças armadas nacionais e do alistamento militar obrigatório. Assim, uma rápida olhada diante da meteórica trajetória intelectual de Olavo Bilac no mundo das letras da Primeira República nos permite entrevê-lo como precoce e culturalmente consagrado em meio ao seu campo intelectual (BOURDIEU, 1968), e tal constatação quanto à sua privilegiada posição de classe, diga-se de passagem, já bastante ratificada por vários autores que trabalharam a sua trajetória intelectual, nos permite ressaltá-la como principal fator para a enorme proximidade de nosso autor tanto em relação a nomes 
referencias para os círculos letrados da época tais como João do Rio, Coelho Neto, entre outros, como perante importantes "atores" da política republicana que chegaram a lhe render alguns cargos na burocracia estatal tal como o ratifica Álvaro Simões em A Sátira do Parnaso:

Com a crescente popularidade, as oportunidades não deixaram de aparecer. Em 1900, acompanhou, como representante da Gazeta de Notícias, o presidente Campos Salles em viagem à Argentina, onde fez as vezes de orador oficial - com grande sucesso. Em 1906, foi nomeado secretário-geral da III Conferência Panamericana, realizada no Rio de Janeiro, o que demonstrava o seu prestígio perante o barão do Rio Branco. No ano seguinte tornou-se secretário do prefeito do Distrito Federal, Souza Aguiar. (JÚNIOR, 2007, p.61) 3

É neste quadro que nos revela as estreitas relações então existentes entre a consagração intelectual de Olavo Bilac e as suas conquistas profissionais, tanto no mundo intelectual como no mundo político, que devemos conceber o seu notório entusiasmo pela proclamação, o seu total apoio à República bem como a sua ótica

3 Ainda vale destacar que no curto mandato de Francisco Portela, primeiro governador do Estado do Rio de Janeiro durante a República, Olavo Bilac foi nomeado para a Secretaria do Interior junto de outros letrados como Coelho Neto e Aluísio Azevedo, que assumiram respectivamente as funções da Secretaria de Governo e de oficial da Fazenda. Em dezembro, com a saída de Portela devido à pressão dos tempos florianistas, Olavo Bilac e seus companheiros acabaram também retirados de seus cargos. 
bastante crítica ante aquele jovem regime pelo qual tanto lutou e que ainda entendia como muito distante de parâmetros verdadeiramente republicanos.

Portanto, julgamos de fundamental importância analisar a perspectiva do intelectual Olavo Bilac a respeito do inédito regime republicano brasileiro e para tal pretendemos não apenas captar as diferentes representações que o autor veiculou sobre este, mas também trabalhá-las de modo a melhor compreendermos as suas possíveis motivações políticas, ideológicas e culturais bem como que determinações ou influências a sua ótica sofreu por parte do processo histórico que então lentamente consolidava não somente o jovem regime republicano, mas o ainda frágil capitalismo brasileiro.

Especificamente a respeito da historiografia que trata da trajetória intelectual de Olavo Bilac, gostaríamos de ratificar que alguns trabalhos nos são extremamente caros, sobretudo os desenvolvidos por Antônio Dimas, que reuniu em coletânea milhares das crônicas de nosso autor espalhadas pela imprensa da época, os diversos artigos de Magali Engel, que nos ajudam bastante a melhor compreender a importância das relações de sociabilidade que Bilac estabeleceu em seu tempo bem como dos espaços de militância nos quais atuou, desde a imprensa até organizações civis como a LDN, e a obra basilar de Álvaro Simões que, embora enfoque a poesia satírica de Bilac, é de fundamental importância para nós por ratificar a sua condição de intelectual orgânico gramsciano, oriundo de frações das classes dominantes daqui, bem como o seu não-alheamento de diante das principais problemáticas do Brasil da época, "rótulo" comumente 
atribuído aos integrantes do movimento parnasiano. Ademais, é importante fazer justiça e lembrar que tanto Magali Engel como Antônio Dimas também convergem com o entendimento de Álvaro Simões de que Olavo Bilac foi sim um intelectual militante e bastante dedicado à reflexão e abordagem de questões que afetavam o Brasil, sendo elas de cunho social, econômico, político e cultural. Como algumas vezes o demonstrou, Bilac percebia o Brasil e sua nação como em meio a um importantíssimo processo civilizatório e como indício de tal perspectiva é válido atentarmos para a sua clara adesão, bastante evidente no decorrer das reflexões que elaborou, às noções burguesas de civilização e progresso, que à época apenas ratificavam o modelo de sociedade europeu como referencial a todos os países que ainda se encontravam em notório atraso social, sendo o próprio Brasil um típico exemplo nesse sentido para grande parte dos círculos intelectuais nacionais.

Por último, vale destacar também a centralidade assumida pelo espaço da cidade do Rio de Janeiro em nosso trabalho, pois, assim como outros muitos letrados de seu tempo, Olavo Bilac teve na cidade carioca a consagração cultural de suas carreiras de poeta e cronista bem como a consolidação das relações de sociabilidade que lhe renderam o capital social fundamental tanto à sua meteórica ascensão profissional no mundo das letras quanto à grande proximidade que conseguiu estabelecer com muitos dos profissionais da política brasileira. Em suma, era a cidade do Rio o espaço que legitimava as carreiras dos literatos brasileiros coevos aos anos daquela virada de século e, além de capital federal, era a "cidade 
maravilhosa" o nosso centro político, populacional, econômico, financeiro e cultural. Desde meados do século XIX, na cidade carioca se concentravam boa parte das levas de imigrantes estrangeiros e nacionais, dos investimentos governamentais, das indústrias também estrangeiras e nacionais, o maior porto do país e as nossas principais instituições políticas, educacionais e culturais.

Em síntese, pretende-se no espaço deste artigo, analisar as impressões veiculadas pelo jornalista Olavo Bilac a respeito do sistema de governo republicano brasileiro tendo em vista perscrutar quais razões, e suas diversas naturezas, o levaram a construir a sua perspectiva caracteristicamente oscilante e ambígua a respeito daquela República que comumente chamou-se por "oligárquica". Como já afirmamos anteriormente, o nosso recorte cronológico compõe-se dos anos compreendidos entre 1897 e 1908 e adotamos a cidade do Rio de Janeiro como espaço privilegiado de nossa análise.

Em meio às nuances históricas ressaltadas pela historiografia que analisou o golpe de Estado de 1889 e o importante processo de consolidação daquela República que seria dominada pelo poder das oligarquias, temos conosco que o cronista Olavo Bilac, tal como ele mesmo ratifica em alguns de seus escritos, presenciou ativa e entusiasticamente estes decisivos momentos que representaram inéditas mudanças de viés político para aquele Brasil que até então só havia conhecido a monarquia como sistema de governo. Assim, indubitavelmente pode-se dizer que a vivência que o poeta-jornalista Bilac teve deste contexto histórico assim como os diversos vestígios históricos que nos deixou, e nos quais revela bastante de suas 
impressões sobre o mesmo, nos autorizam a um aprofundamento analítico a fim de melhor compreender o significado das representações que publicou sobre o regime republicano pelo qual militou ao longo das últimas décadas do século XIX. E para nos aprofundarmos nas impressões do cronista Olavo Bilac sobre aquela República brasileira que não somente contou com a militância bilaquiana, mas de outros intelectuais importantes como Coelho Neto, Aníbal Falcão e Silva Jardim, de início julgamos bastante interessantes duas crônicas de conteúdos um tanto semelhantes, embora publicadas em dois jornais circulantes em diferentes localidades, ou seja, nas cidades do Rio de Janeiro e São Paulo.

Em primeiro lugar, aquela que foi publicada no jornal paulistano. "Dia ardentíssimo", esta foi a representação que nosso autor nos deixou em crônica publicada no jornal Correio Paulistano, do ano de 1907, ao escrever sobre os movimentos ocorridos na cidade do Rio de Janeiro e que concretizaram o golpe republicano do dia 15 de novembro de 1889. Naquela crônica publicada no aniversário da Proclamação da República, Olavo Bilac procurava detalhar quem estava presente naqueles primeiros e intensos instantes da invasão à Intendência municipal e dos quais havia participado ativamente: "Nunca esquecerei, em cem anos que viva, os colarinhos empastados, os lenços ensopados, as faces inundadas, com que Lopes Trovão, Silva Jardim, Aníbal Falcão, Mallet e cem outros invadiram o salão nobre da Intendência". (BILAC, 15/11/1907). Ali, o cronista ressaltava que a República só havia sido proclamada na madrugada do dia 16 e tendenciosamente indicava que fora da casa 
de Deodoro da Fonseca era imensa a multidão que se colocou a ouvir Benjamim Constant dizer que seria o povo quem escolheria a nova forma de governo do país. Em seguida, lembrava Olavo Bilac que como resposta à fala do militar houve um grito, um sonoro "já escolheu!" vindo de seu amigo Aníbal Falcão.

De todo modo, o que gostaríamos de destacar nesta crônica oriunda do jornal Correio Paulistano é justamente a tendenciosidade da descrição feita por Olavo Bilac, que de modo dramático e glorioso destacou os principais momentos e envolvidos no golpe republicano, afinal, aquele dia quinze, supostamente intenso e caloroso, era então abordado sob um ponto de vista bastante pessoal e em ocasião de comemoração à proclamação naquele novembro de 1907. Contudo, algumas palavras mais do próprio cronista, já passados dezoito anos do acontecimento histórico do qual participou, são importantes para compreendermos um pouco mais de sua ótica entusiasmada acerca da ascensão do primeiro regime republicano da história do Brasil:

Lendo hoje o programa dessas festas, deixei-me ficar algum tempo a reconstruir, na memória, todas as horas vibrantes daquele ardente 15 de novembro de 1889. Dia ardentíssimo! fazia um calor... revolucionário! [...] E durante cinco minutos, os 'vivas' à República retumbaram no ar... [...] Quando saímos dali, passamos pelo Corpo de Bombeiros [...] E um oficial, cujo nome esqueci, teve à passagem da multidão, um belo gesto e um belo grito: mandou a força apresentar armas ao povo. Isto contado assim, depois de tantos anos, pode parecer frio e incolor...Mas naquele momento de excitação, foi uma coisa épica! a massa popular delirou, e seguiu a acordar toda a cidade, numa vozeria ensurdecedora...(BILAC, 15/11/1907) 
Tal descrição daquela virada do dia 15 para o dia 16 de novembro certamente detém alguma verossimilhança com o ocorrido, afinal, o próprio Bilac havia presenciado os fundamentais momentos do nascimento da República, segundo ele próprio, desde a invasão à Intendência até a madrugada do dia seguinte quando acabou escutando de um velho conhecido que tal acontecimento nada mais era do que "fogo de palha". Todavia, dois pontos, a nosso ver, devem ser ressaltados. Em primeiro lugar, a ênfase dada por Olavo Bilac no que se refere à presença popular nas ruas do centro da cidade carioca, pois é nítido na crônica publicada que o autor procurou ali representar aquele momento de brusca virada política e institucional como ansiosamente aguardado por todos. Aos olhos de Olavo Bilac, o "entusiasmo" era o sentimento mais difundido na caminhada daquela "massa" dita delirante por conta do fim da monarquia.

E ainda que consideremos a relativa verossimilhança possivelmente presente no relato do jornalista Bilac, é forçoso notarmos certo exagero e demasiada coerência na descrição que fez do golpe, uma vez que as suas lembranças sutilmente indicam a chegada da República no Brasil com ampla base popular e suficiente legitimidade perante a mesma, o que, como pudemos ver, é amplamente rechaçado por diversos estudos históricos mais. Por outro lado, vale destacar que havia certa "incoerência" relativamente nítida no relato de nosso autor e que "minava" a sua descrição da população local como excitada pelo evento da proclamação, pois, ao se observar a crônica publicada no Correio Paulistano em sua 
totalidade, constata-se que linhas antes da descrição de tom heroico sobre o golpe, já constava certa afirmação do jornalista Bilac que apontava para um histórico desapego da população carioca à data de 15 de novembro, afinal, "Pela primeira vez, será festejada, no Rio, com algum entusiasmo, a data da proclamação" (BILAC, 15/11/1907). Ou seja, temos a proclamação como historicamente desprezada e ao mesmo tempo como muito festejada, sobretudo pela mesma população local da cidade do Rio de Janeiro.

A partir destas primeiras impressões e memórias de Olavo Bilac em relação àqueles dias do golpe de novembro de 1889, é possível já percebermos uma excessiva coerência de sua parte quando se propôs a relatar o desenrolar daquele evento histórico que presenciou, sobretudo quando destaca em seu texto a suposta legitimidade que o golpe tinha aos olhos da população local que era descrita não somente em termos de afeita à República, mas como extasiada pela inauguração da mesma. Ali, Bilac sutilmente representava ao seu leitor aquele golpe republicano de sua juventude como uma "realização" ansiada por grande parte daquela "massa" presente, embora como vimos, um tanto contraditoriamente. Por outro lado, a reforçar o nosso ponto de vista, enfatizamos que tais lembranças estão dispostas na crônica de modo semelhante a um relato autobiográfico, gênero no qual muitas vezes podem ser observadas construções de sentido dadas a posteriori e que emprestam a momentos passados outras coerências e significados comumente ligados a interesses de períodos posteriores; assim, é justo que tenhamos conosco a possibilidade de que aquela descrição 
de Olavo Bilac acerca do golpe, em tom de excitação popular e heroicidade dos envolvidos, então atendesse a interesses oriundos de seu presente de jornalista do órgão oficial do PRP, o Correio Paulistano, ou simplesmente a título de louvação da data que percebia como pouco festejada em nossa curta vida de República.

O segundo ponto diz respeito ao significado político dado por Olavo Bilac à inauguração da República, bastante evidente tanto na citação acima como no desfecho que elaborou e no qual descrevia o raiar do dia seguinte em meio às previsões pessimistas de um conhecido que jurava ser o golpe apenas mais uma "bernarda indigna" a ser reprimida pelas tropas imperiais. Neste relato fica um pouco mais clara a interpretação que Olavo Bilac tinha para si da chegada da República na vida política do Brasil, sendo a deposição da monarquia ainda que através de um golpe, uma positiva e importante "revolução". Ou seja, era desejo de nosso autor e havia o entendimento por parte do mesmo de que o golpe de 1889 havia sido sim uma "revolução" fundamental à evolução política do Brasil rumo à modernidade dos moldes liberais então representados pelas potências europeias, sobretudo França e Inglaterra, assim como pelas repúblicas latino-americanas que desde as suas independências foram justamente sinônimo de instabilidade política aos olhos do Império da linhagem dos Bragança. A título de ilustração, destacamos a narrativa de Bilac sobre a noite do dia 15 para o dia 16 na qual, talvez sem maiores intenções, nos afirmava um pouco mais sobre a acepção que dava ao golpe. $\mathrm{O}$ autor então demonstrava que considerava a República como superação e ruptura em termos políticos e 
institucionais frente àqueles tempos da morosidade típica da "rotina imperial":

Pardal Mallet e eu separamo-nos da multidão delirante, que continuava a percorrer as ruas, e fomos almoçar, jantar e cear ao mesmo tempo. [...] Enfim, depois de muito procurar, sempre encontramos comida em uma casa de pasto da rua da Constituição. E lá descobrimos um conhecido, cujo nome não quero citar. Estava indignado! Achava a revolução uma 'bernarda indigna'. E disse-nos: - 'Felizmente, isto é fogo de palha! Amanhã, assim que o Imperador descer de Petrópolis, estes soldados insubordinados serão punidos, a canalha será corrida, e terá fim esta farsa abominável!...' (BILAC, $15 / 11 / 1907)$

Portanto, podemos depreender do trecho destacado que aos olhos do republicano Olavo Bilac seria a República fruto não de uma "bernarda indigna" liderada por um mero bando de "soldados insubordinados". Era ela ao mesmo tempo superação e ruptura com o nosso indesejado passado colonial e imperial tão bem representado pela continuidade de reinados dos Bragança. Em suma, uma fundamental "revolução" que havia tirado o Brasil de um atrasado, escravista, decadente e letárgico sistema de governo monárquico, e que o colocou nos trilhos do progresso que caracterizava a era de modernidade que se abria no Ocidente então sob grande influência dos pensamentos científico e liberal. Por outro lado, vale destacar que esta perspectiva de Olavo Bilac que tratava a República como uma revolução, a nosso ver demonstra que o poeta-jornalista tinha para si o entendimento frisado pelo historiador Renato Lessa de que a 
legitimidade do regime republicano estava em sua origem revolucionária (LESSA, 2001, p.22), ou seja, a percepção bilaquiana de exaltação da República como uma reviravolta completa em nossa vida político-institucional apenas ratifica que nosso autor inseria-se por completo naquele clima que envolveu o golpe e que agitou a cidade carioca em meados de novembro de 1889. E a título de ratificação quanto à aceitação de Olavo Bilac quanto à legitimidade daquela República em sua origem revolucionária, podemos nos voltar a uma das várias descrições do autor acerca do líder da proclamação, Deodoro da Fonseca, e que o apresenta através de contornos de heroísmo e sacrífico pessoal; o "velho Deodoro" contava com enorme simpatia por parte de nosso autor que chegou a se envolver num levante a seu favor em abril do ano de 1892. Enfim, segundo o cronista,

\footnotetext{
Deodoro, muito pálido, agitava as mãos no ar, agradecendo as ovações. E nunca mais esquecerei o aspecto da figura do grande soldado, naquela noite, com o perto num arquejo que parecia querer romper a farda abotoada, a boca aberta pedindo ar, a bela face de leão demudada pelo sofrimento, e a clara barba oscilando, subindo e descendo, ao esforço do ofego... (BILAC, 8/1/1905) ${ }^{4}$
}

$4 \mathrm{Na}$ edição do Correio Paulistano mencionada, o nosso jornalista chegava a representar heroicamente general Deodoro da Fonseca: "O velho soldado ansiava, ofegava, arquejava, numa crise de moléstia que o devia matar. Não podia falar: respondia às aclamações com a mão espalmada, batendo o ar. E o seu olhar brilhava lá em cima, na meia escuridão da janela, brilhava de febre, de orgulho, de 
Agora, passamos ao outro registro cronístico publicado na popularíssima Gazeta de Notícias. No popular jornal carioca, Olavo Bilac, em 8 janeiro de 1905, embora tenha construído outra descrição daquele dia do golpe republicano, esta se mostrou bastante semelhante e alinhada à citada anteriormente, o que a nosso ver só vem a reforçar a possibilidade de verossimilhança quanto ao conteúdo veiculado na descrição do autor sobre os intensos momentos do dia 15 de novembro de 1889. Naquela Gazeta o jornalista novamente trazia à tona as suas lembranças, mas desta vez impulsionado por uma resolução que o presidente Rodrigues Alves à época aprovaria pela desapropriação da antiga casa do marechal Deodoro da Fonseca. Bilac então recorreria a momentos semelhantes aos já citados na crônica publicada no Correio Paulistano para descrever o golpe bem como a representações bastante positivas sobre o mesmo, ratificando assim que a sua interpretação acerca do movimento militar que depôs Dom Pedro II, era a de que este havia sido sim uma "revolução vitoriosa", ocorrida em meio à "multidão [que] burburinhava: era um mar agitado, tempestuoso, ondulando a perder de vista..." (BILAC, 8/1/1905). No decorrer do texto o cronista voltava a se remeter aos acontecimentos daquele quinze de novembro como acompanhados pelas massas nas ruas do Rio e pela imprensa local, chegando à louvação de alguns nomes que participaram

entusiasmo... e de sofrimento. O nobre leão já tinha os seus dias contados: espreitava-o a Morte, naquela noite decisiva para sua vida gloriosa." (BILAC, $15 / 11 / 1907)$ 
ativamente daquele dia, a exemplo do muito elogiado marechal Deodoro da Fonseca então representado como um "grande soldado" que, mesmo doente, ainda se pôs a saudar os que lá fora davam vivas à República. Assim como na crônica do jornal paulistano, na publicação da Gazeta de Notícias Bilac novamente construiu uma representação daquelas horas do golpe como parte de uma "jornada revolucionária" que resultou numa dita "revolução vitoriosa" e que teve como líderes os ditos "chefes da revolução". (BILAC, 8/1/1905)

Com base nas linhas que acima esboçamos, é lícito constatarmos a esta altura que as referências feitas por Olavo Bilac ao golpe republicano, além de bastante entusiásticas, elogiosas e permeada por tons de heroicidade, procuravam representá-lo principalmente como uma fundamental ruptura na vida política do país, ou mais especificamente, como uma "revolução" que havia nos livrado da letargia imperial na efetivação de reformas sociais modernizadoras e que atendeu aos anseios da multidão que, segundo o próprio cronista, com certo exagero, não permitiu nem o discurso do militar Benjamim Constant, pois então delirantemente festejava a República recém-inaugurada. Entretanto, para além desta prévia noção em relação à perspectiva de Bilac sobre a inauguração do regime republicano, ainda cabem algumas observações mais detidas e que ultrapassem a mera descrição das representações que veiculou tanto no Correio Paulistano como na Gazeta de Notícias.

Em primeiro lugar, é fundamental que tenhamos em vista o perfil de ambos os meios de comunicação nos quais Olavo Bilac veiculou a sua representação bastante positivada sobre o golpe de 
1889. Queremos dizer que levar em conta os perfis dos jornais nos quais Bilac publicou as duas crônicas acima, é importante para que tenhamos em mente a possibilidade de que o conteúdo veiculado por nosso autor em maior ou menor medida possa ter sofrido interferências por exigências exteriores à sua inventividade $\mathrm{e}$ pensamento político, afinal, o contexto histórico da Primeira República foi atravessado por inúmeros ataques à liberdade de imprensa, contou com diversos periódicos a serviço de interesses oligárquicos e governamentais etc.

Tanto a Gazeta de Notícias como o Correio Paulistano, apresentaram uma linha editorial histórica e marcadamente republicana, algumas vezes mostrando-se comprometidos com o regime estabelecido em 1889, embora não possamos estabelecer seus quadros como homogeneamente republicanos. No caso da Gazeta, jornal bastante popular em seu tempo, com altas tiragens, de preço acessível e uma das primeiras folhas a preencher suas oficinas com diversos nomes do mundo literário, deve-se levar em conta que, embora tenha sido um dos primeiros jornais a adotar o perfil da neutralidade jornalística, foi durante anos chefiada pelo republicano assumido Ferreira de Araújo e chegou a contar em suas oficinas com nomes de grande notoriedade justamente pelo seu posicionamento a favor do novo regime tais como o próprio Olavo Bilac, Coelho Neto, Silva Jardim, dentre outros mais. O Correio Paulistano talvez expresse melhor o motivo de nossa ressalva quanto a possíveis determinações ou "mediações" exteriores à inventividade bilaquiana, pois, tal jornal, apesar de criado ainda no Império e das inúmeras 
modificações que sofreu em seu posicionamento político por conta de seus diversos proprietários, após 1890 estabeleceu-se definitivamente como órgão oficial do Partido Republicano Paulista. Destacamos ainda que o Correio chegou a defender, tal como Bilac, a proclamação da República, a Abolição da Escravatura e a contar com nomes importantes, ligados ao PRP, tais como Oswald de Andrade e Menotti Del Picchia. Contudo, julgamos importante levantar tais observações a fim de não tomarmos ingenuamente as impressões e caracterizações feitas por Olavo Bilac em ambos os jornais, afinal, embora consideremos como válida a proposição de que a produção cronística bilaquiana expressava sim o pensamento político de seu autor, em tempos como de uma República tipicamente oligárquica, de jornais e revistas altamente tendenciosos, de posicionamentos muitas vezes determinados por grupos políticos, é importante que não tomemos os escritos jornalísticos bilaquianos como límpidos e transparentes indícios daquilo que realmente pensou o autor acerca da chegada do regime republicano, sobretudo quando escreveu justamente naqueles jornais que apontavam mais claramente para o alinhamento à ordem republicana estabelecida. De qualquer forma, de maneira nenhuma pretendemos questionar o engajamento de nosso cronista em prol do sistema de governo republicano, pois sua militância e posicionamento político, alinhados à causa republicana, são consensuais a diversos estudos históricos que se detiveram sobre a sua trajetória intelectual. Apenas levantamos os perfis históricos de ambos os jornais como possíveis "agentes influenciadores" sobre o processo de produção intelectual do autor, e consequentemente, 
sobre o conteúdo das crônicas anteriormente destacadas, por termos em mente que tais periódicos daquele período da Belle Époque eram, em maioria, tanto detentores de perfil empresarial como bastante afetados pelos grupos políticos coevos, realidade esta que a nosso ver nos autoriza a ter o conteúdo veiculado em suas páginas como possivelmente vinculado a interesses de ordem política, partidária, meramente financeira, entre outros mais.

Em segundo lugar, inevitavelmente temos de relacionar o conteúdo expresso em ambas as crônicas como em grande parte produto da militância dos tempos de juventude de nosso jornalista em prol da República e da abolição dos escravos. Levar em conta este ponto de sua trajetória é fundamental para compreendermos a ênfase e o entusiasmo contidos em seus escritos sobre aquelas intensas horas que vivenciou em meados de novembro de 1889. Ademais, alguns outros relatos contextualizam e embasam um pouco mais essa perspectiva de que era intenso o apreço do jornalista pela República em nome da qual tanto lutou e vale destacar certa crônica que se revela bastante ilustrativa nesse sentido, pois nos traz a revolta de Olavo Bilac diante da recusa de seu diploma de eleitor por parte da junta de alistamento eleitoral da cidade do Rio de Janeiro. Naquela ocasião, o cronista, embora em meio a um professado asco pelas corrompidas instituições republicanas, ainda encontrava espaço para afirmar a si mesmo como "Ferozmente, horrendamente republicano" (BILAC, 31/3/1907). Desta forma, julgamos lícito apontarmos para a juventude militante de nosso autor como um importante fator na composição de sua escrita em tom ao mesmo tempo nostálgico e 
efusivo sobre o golpe de Estado que derrubou a monarquia brasileira, afinal, como o próprio Bilac afirmou, as campanhas abolicionista e republicana eram, a seu ver, interdependentes e "que outra causa, tão bela e tão nobre, ainda pode tentar as almas jovens?" (BILAC, $15 / 5 / 1908)$

Em terceiro lugar, tais observações entusiásticas por parte do cronista Bilac em relação à República, podem ser consideradas como reflexo de sua posição de classe privilegiada, pois, como a maioria de seus pares intelectuais, nosso autor aderiu ao novo regime e ao longo do mesmo pôde manter, embora não sem alguns avanços e retrocessos, a exemplo de seu desencanto com a República quando do autoritário mandato de Floriano Peixoto, notório prestígio, influência e proximidade em relação à ordem estabelecida e seus profissionais; por outro lado, o posto privilegiado e consagrado de Olavo Bilac no campo intelectual de seu tempo, torna suas impressões positivas sobre a República ainda mais inteligíveis já que as instâncias de consagração cultural naquele jovem regime mostravam-se ainda intimamente ligadas a diversos agentes do campo do poder e do campo político. A título de exemplo, lembramos o próprio Correio Paulistano, como jornal ligado ao principal partido da Primeira República, o PRP, e a Academia Brasileira de Letras, da qual Bilac foi um dos fundadores e na qual, segundo Maurício Silva, "o autor acadêmico era considerado um elemento indispensável ao regime político e ao governo estabelecido, em oposição a outros atores do cenário artístico sem expressão reconhecida". (SILVA, 2007, p.72) Ou seja, considerando o campo 
intelectual da Primeira República como pouco autônomo em relação a influências exteriores, sobretudo do campo do poder, pois ainda em vias de constituição, é fundamental percebermos que as instituições e os agentes que compõem o primeiro inevitavelmente sofrem os efeitos de sua heteronomia (BOURDIEU, 2004, p.22), daí advindo a possibilidade de compreendê-los como ainda em íntima relação com a esfera da política, com a consolidação das estruturas de dominação inerentes ao novo regime e com seus projetos de legitimação simbólica e político-institucional. Para maior contraste, basta nos voltarmos à escrita de Lima Barreto, coeva à de Olavo Bilac, embora de total oposição à República. Assim, em relação ao cronista e romancista Lima Barreto, devemos percebê-lo justamente como relativamente marginalizado em seu campo intelectual por ter se mostrado inclinado aos ideais anarquistas e socialistas bem como contrário ao status quo republicano, embora outros fatores possam ser ressaltados para um entendimento mais completo de sua posição desfavorecida em relação aos consagrados círculos intelectuais da época tais como a sua condição de classe desfavorecida e o estigma da negritude em tempos de forte preconceito racial. Contudo, é significativa a relação entre a rejeição do nome de Lima Barreto à cadeira na Academia Brasileira de Letras, a sua difícil inserção e consagração no campo intelectual da época e a conjunção dos fatores que anteriormente citamos, sobretudo a sua militância literária contra a República brasileira.

Também se pode perceber nas entrelinhas das crônicas selecionadas certa interpretação por parte de Olavo Bilac que não 
somente enxergava como legítimo aquele golpe militar que havia deposto a monarquia de Pedro II, mas que também visava a difundir por seu público leitor a legitimidade de que tanto necessitava a nascente e historicamente "necessária" República brasileira, esta certamente ainda bastante carente da adesão das descrentes e exploradas classes populares. Nesse sentido, lembramos que a historiografia relativa ao período ratifica justamente esta perspectiva de grande afastamento da população comum em relação à ordem republicana constituída, pois, apesar da propagação que esta última efetivou em seus discursos das ideias de cidadania, democracia, progresso e ordem, ainda era evidente a enorme distância que havia para a concretização das mesmas, afinal, inúmeras mazelas ainda afetavam a nossa realidade social sendo exemplares os altos números do analfabetismo, as diversas epidemias mortais, a constante carestia dos gêneros alimentícios, uma abismal desigualdade socioeconômica, práticas políticas das mais truculentas e abomináveis como as fraudes eleitorais e o chamado voto de cabresto, bem como o grande desinteresse e afastamento dos segmentos populares da participação política através do voto.

Para termos uma melhor noção do alcance da legitimidade que Bilac provavelmente pretendia difundir a fim de contribuir para a consolidação do novo regime, podem ser levadas em conta algumas observações de Pierre Bourdieu ${ }^{5}$ acerca do conceito de campo

${ }^{5}$ Segundo o sociólogo francês, "Conclui-se que as relações que cada intelectual pode manter com cada um dos outros membros da sociedade intelectual ou com o público e, a fortiori, com toda a realidade social exterior ao campo intelectual 
intelectual e que nos permitem perceber que, sendo Olavo Bilac detentor privilegiada posição de classe e de significativo capital simbólico, este resultante da consagração imposta pelas instituições culturalmente legitimadoras de seu tempo tais como a já citada Academia Brasileira de Letras e a importantíssima Gazeta de Notícias, seguramente era expressiva a sua capacidade de contribuição para a legitimação simbólica do inédito e jovem regime. Aos olhos de nosso autor, a República havia sido um tremendo avanço de nosso país em termos de sistema de governo e afigurava-se como o regime político tipicamente moderno tal como a democracia norte-americana e as repúblicas latino-americanas nossas vizinhas. Portanto, a nosso ver é extremamente válido perceber as impressões bastante positivas e elogiosas de Olavo Bilac a respeito da República e de seu golpe inaugural não somente como indicadores de que realmente as enxergava como parte de um processo histórico fundamental ao país, pois politicamente modernizante, mas também como indícios de que seu engajamento visava à difusão de uma representação da República como um sistema de governo legítimo e altamente necessário àquele atrasado Brasil que conviveu por décadas

(como sua classe social de origem ou de fato, ou poderes econômicos enquanto vendedores ou compradores) são mediatizadas pela estrutura do campo intelectual ou, mais exatamente, por sua posição em relação às autoridades propriamente culturais cujos poderes organizam o campo intelectual". (BOURDIEU, 1968, p.132). 
com uma monarquia morosa e surda aos inúmeros apelos por reformas modernizadoras de cunho social, econômico e político. Um último ponto que gostaríamos de abordar e que diz respeito à referida interpretação bastante positivada por parte de Olavo Bilac acerca da República brasileira, está relacionado à possibilidade de interpretarmos tal perspectiva bilaquiana como resultado das influências ideológicas e filosóficas sofridas por nosso autor, sobretudo pelas emergentes culturas democrática e científica de final dos Oitocentos, afinal, enquanto parte dos principais círculos intelectuais da Primeira República, seguramente Olavo Bilac manteve estreito contato com tais ideias então patentes nos posicionamentos que adotou em prol da República no Brasil, a favor das liberdades básicas, civis e políticas, inerentes a este regime, e de oposição ao Império de Pedro II que rotulou inúmeras vezes como obsoleto, caduco e atrasado frente às muitas "virtudes" intrínsecas ao regime republicano. Assim, a influência que Olavo Bilac sofreu pela grande circulação destas filosofias também é importante de ser levada em conta para melhor compreendermos a sua ótica bastante positiva sobre a República brasileira, afinal, tais correntes de pensamento, certamente bem conhecidas por nosso jornalista, também tratavam, sobretudo a filosofia positivista, da superioridade e da inevitabilidade histórica do regime republicano frente ao monárquico, entre outras temáticas mais. Segundo Maria Tereza Chaves de Mello, autores basilares às correntes de viés democrático e científico bem como caros à intelectualidade nacional daquele contexto histórico, entendiam a história dos homens no mundo como um processo 
histórico de sentido literalmente evolutivo, valendo destacar a centralidade que a ideia de progresso possuía para tais pensadores europeus e brasileiros neles inspirados:

Tanto Comte quanto Spencer entendiam o desenrolar da história humana como uma sucessão escalonada de superações, pelas quais a religião e a monarquia eram valores de um passado caduco. Todas as sociedades caminhavam inexoravelmente para o advento de um mundo guiado pela ciência e pela democracia. Nessa cultura científica e democrática o regime republicano era uma necessária culminância política. (MELLO, 2008, p.19)

Assim, é justo indicarmos o relato e o próprio pensamento de Olavo Bilac sobre a República, o seu golpe inaugural, e a sua importância enquanto regime moderno e comprometido com o futuro do país, como formado ideológica e politicamente naquele contexto histórico marcado pela transição das disposições mentais consolidadas pela monarquia, pelo declínio do sistema simbólico que mantinha de pé e legitimava o Império de Pedro II e pela plena ascensão das emergentes filosofias democrática e científica logo acima mencionadas. Um exemplo bastante ilustrativo acerca deste processo transitório então dado no campo das ideias e mentalidades é a paulatina expansão do campo semântico referente ao termo "república", ocorrida de modo concomitante e intricada ao lento declínio do regime imperial conforme ressaltou a historiadora Maria Tereza Chaves de Mello. Uma outra faceta desta transição no âmbito das disposições mentais estava na enorme difusão então conquistada 
pelos ideais republicanos também destacada pela autora que lembra os espaços da imprensa, da literatura e dos partidos como fundamentais a tal processo que ainda incluía tanto a construção de uma visão sobre a República como moderna, pois apoiada nas emergentes ideias científicas e democráticas, como a desconstrução da legitimidade simbólica intrínseca à monarquia de Pedro II através de representações bastante pejorativas e em geral opostas àquelas referentes à República. Enfim, segundo a autora, os pares antônimos eram a tônica nos inúmeros discursos veiculados à época e portanto,

à monarquia vão se colando termos tais como: tirania, soberania de um, chefe hereditário, sagrado e inimputável, privilégio, súditos, apatia, atraso, centralização, teologia. Em contraposição, à república são associadas as ideias de liberdade, soberania popular, chefe eleito e responsável, talento ou mérito, cidadania, energia, progresso, federalismo, ciência. Enfim, de um lado, o passado; de outro, o futuro. Frente ao despotismo, a 'democracia pura'. (MELLO, 2008, p.16)

Levando em conta uma das propostas da autora quanto a esta crescente disposição mental da população brasileira para a inédita República, decorrente da incorporação desta cultura marcadamente cientificista e republicano-democrática em ascensão bem como do declínio do sistema simbólico que sustentava o regime imperial, julgamos lícito situar a representação extremamente positivada de Olavo Bilac como inserida, e ao mesmo tempo, reflexo deste contexto que não apenas lhe influenciou ideológica e politicamente, mas que o teve como importante agente histórico, afinal, como já ressaltamos, é 
bastante conhecida a sua militância dos anos de juventude em prol tanto da causa abolicionista como da republicana. Daí, ao percebemos que a República no último quartel do século XIX passou a ter como associada a si própria ideias como as de "progresso", "futuro", "liberdade" e "soberania popular", podemos melhor compreender o aspecto simbólico da representação que Bilac transmitiu aos seus leitores da Gazeta e do Correio sobre a chegada do novo regime como intimamente acompanhado pela população comum assim como quanto à soberania popular que a proclamação final e supostamente havia conquistado, por meio daquela dita "revolução", então liderada pelo nobre "leão" Deodoro da Fonseca.

Em caráter complementar à esta percepção que ressalta a interpretação de Olavo Bilac sobre a República como acompanhada de perto pela população comum e como uma importante revolução de âmbito político-institucional, destacamos que tais impressões e caracterizações, aliadas a outros escritos cronísticos de sua autoria, nos permitem ir um pouco mais além e afirmar que o novo regime para nosso autor também seria resultado das lutas políticas e sociais de que participou já no final do século XIX, contexto histórico no qual, segundo Maria Tereza Chaves de Mello, era difundido anseio por reformas sociais, políticas e econômicas por parte do regime monárquico ${ }^{6}$. Para ratificar tal proposição, voltamos a algumas linhas já citadas do cronista Bilac que ao escrever sobre a abolição dos

\footnotetext{
${ }^{6}$ Segundo Maria Tereza Chaves de Mello: “A palavra de ordem era então, reforma. Reformas para acelerar o advento do télos - de qualquer maneira inevitável, segundo entendiam - progresso-civilização.” (MELLO, 2007, p.10)
} 
escravos e sua militância em prol desta causa, dizia ser a República a consequência natural desta mesma militância abolicionista dos anos 1880, pois, "Feita a abolição, e feita a República, que era a sua consequência lógica e fatal, - que outra causa, tão bela e tão nobre, ainda pode tentar as almas jovens." (BILAC, 15/5/1908). Ou seja, muito provavelmente era a República historicamente inevitável ${ }^{7}$ aos olhos do jornalista e intelectual Olavo Bilac, pois parcela integrante e fundamental de uma ampla gama de transformações de diversos matizes que viriam a cumprir a urgente tarefa da modernização de

${ }^{7}$ Em artigo, Maria Tereza Chavez de Mello interpreta que no contexto de crise do regime imperial, o ressurgimento do movimento republicano e a ampla circulação das filosofias científica e democrática em nossa sociedade, sobretudo em seus círculos letrados, contribuíram bastante para que a República fosse vista como uma “inevitabilidade histórica”. Logo, a nosso ver, é de fundamental relevância ter em mente que o nosso poeta-jornalista, ativamente participou deste contexto histórico e em muito foi influenciado por tais ideias e culturas em emergência. De todo modo, nas palavras da autora: "Entre as discussões dos tempos inaugurais do Estado brasileiro e o momento da autonomia do termo república, vieram à cena, entre outros fatos, o Manifesto Republicano, partidos republicanos, jornais republicanos e, o que é de especial relevância, ampliou-se uma nova cultura pela sociedade brasileira letrada, uma cultura democrática e científica, na qual o regime republicano estava inscrito como uma inevitabilidade histórica. [...] Assim é que, para a aquela geração ilustrada, o regime republicano passou a ser percebido como uma fatalidade histórica. Essa cultura democrática e científica penetrou profundamente na sociedade brasileira do final do Império. Ela renovou o vocabulário e a semântica. Sob suas premissas passaram a se pensar as 'questões' nacionais. O mais importante, é que ela configurou um novo sistema simbólico que colocou em cheque os modelos montados pelos construtores do império, trazendo para a arena pública a percepção da crise de direção que vivia o regime." (MELLO, 2011, p.124) 
nossa sociedade e finalmente a da inserção da nação brasileira nos trilhos do progresso e da civilização, ambos, a seu ver, unicamente viáveis debaixo de um sistema de governo republicano e alinhado à modernidade capitalista ocidental.

No entanto, ainda que a República tivesse atrelada a si própria conceitos e ideias que a representavam de modo claro como o sistema de governo que finalmente inseriria o Brasil nos trilhos do progresso e da civilização ocidental, tal realidade não conseguiu isolar o inédito regime de análises mais realistas e críticas por parte de nosso autor e muitos outros intelectuais seus contemporâneos, embora não devamos abrir mão da compreensão de que boa parte de sua argumentação tinha como fundamental a superioridade do regime republicano em relação ao imperial por alguns motivos que já abordamos. Perceber esta oscilação na análise bilaquiana é fundamental tendo em vista que reconhecemos que o foco de nosso trabalho é justamente a perspectiva de um indivíduo, que como qualquer outro, é dotado de sua subjetividade, o que por sua vez, torna imperativo levar em conta a possibilidade bastante concreta de ter em sua escrita determinadas contradições, ambiguidades, tensões e incertezas. Por outro lado, é forçoso que tenhamos em mente que a República, e seu "molde" político-institucional, era uma das temáticas fundamentais que atravessava o universo intelectual daquele período; nesse sentido, seguindo a lógica do campo intelectual bourdieusiano, o "culturalmente consagrado" Olavo Bilac não poderia ter deixado de tratar, em seus dias de plena atividade intelectual, do bom ou mau "funcionamento" daquela República que 
tanto apreciava, afinal, segundo o próprio sociólogo francês, "O que faz com que um pensador pertença a sua época, o que com que seja situado e datado são antes de mais nada as problemáticas e as temáticas obrigatórias nas quais e pelas quais pensa." (BOURDIEU, 1968, p.141) Ou seja, abordar a "República" era basilar ao debate com outros agentes do campo intelectual e ao próprio pertencimento de Olavo Bilac em relação aos círculos intelectuais da época, embora possamos listar outras "temáticas obrigatórias" aos membros do dito "campo" tais como a problemática do saneamento da capital Rio de Janeiro, a difusão da instrução primária pelo país, dentre outras mais. Um significativo indício do olhar mais realista, ou mais crítico, por parte de Olavo Bilac pode ser encontrado justamente na mesma crônica da Gazeta de Notícias que analisamos logo acima para refletir sobre o seu posicionamento acerca da República. O desfecho da crônica também se revela fundamental, pois, ao mesmo tempo em que traz à tona a perspectiva ressaltada por Maria Tereza Chaves de Mello quanto à República como vinculada a ideias de "futuro" e "progresso", neste caso, então subjacentes à declaração do autor de valorização da instrução primária pelo país e suas benesses, também nos evidencia algumas das mais importantes "falhas" daquele novo regime aos olhos de nosso cronista que na década de 10 intensificaria ainda mais a sua luta pela causa da alfabetização. De qualquer forma, naquela Gazeta Bilac ainda afirmava em tom bastante crítico:

Não sei se o regime republicano pode florescer e frutificar bem, num país que conta no seu seio mais de dez milhões de analfabetos... $\mathrm{O}$ melhor meio de honrar o regime e honrar 
quem o fundou, é associar a memória do fundador à obra santa da instrução primária. Cada criança, das que daquela casa continuarem a sair sabendo ler e escrever, será mais uma criatura livre, capaz de defender, transformar esta República, que, desgraçadamente, ainda parece pensar que pode merecer o nome de homem um animal incapaz de decifrar os caracteres do alfabeto.... (BILAC, 8/1/1905)

A constatação efetivada em crônica é aguçada se lembrarmos que a própria República tinha adotado em sua Constituição de 1891, como um dos critérios para a participação política, a condição do letramento; nesse sentido, é lícito percebemos que a argumentação construída por Olavo Bilac nas linhas acima girava em torno justamente da premência da massificação da instrução primária no Brasil e trazia nas suas entrelinhas o seu desejo de aumento da participação popular naquele regime democrático ${ }^{8}$ no qual os processos eleitorais eram maciçamente despovoados pelos mais

${ }^{8}$ No contexto da Revolta da Vacina, Olavo Bilac chegou a escrever em tom de sarcasmo e crítica a respeito da insegurança nas eleições então ocorridas, embora também tenha ali deixado certo lamento no ar e que tinha como motivação principal a ínfima participação popular nos pleitos há poucos dias realizados: "O dia das eleições não aumentou o número de mortos que daí a quarenta e oito horas tinham de ser visitados. Nem um só cidadão faleceu, no seu posto de eleitor, à beira da urna, vitimado pelo seu fervor cívico. Houve apenas um conflito, apenas um tiro de revólver, apenas um ferimento leve. O candidato mais votado não logrou obter seiscentos votos; pelas notícias da apuração parece averiguado que somente seis mil cidadãos - se tanto! - foram meter cédulas dentro das urnas: os outros cidadãos, que vivem, trabalham ou vadiam, gozam ou penam, aborrecem-se ou divertem-se nesta cidade, não acharam que um curto passeio às seções eleitorais fosse um bom emprego para as primeiras horas da manhã de domingo." (BILAC, 6/11/1904) 
diversos motivos. Nesse sentido, vislumbrando a expansão da instrução para o consequente aumento da participação popular através dos canais oficiais da cidadania política republicana, as eleições, Olavo Bilac de certa maneira se encontrava na contramão das pretensões e concepções de grande parte dos profissionais da política da Primeira República que desde o seu advento, segundo José Murilo de Carvalho, já almejavam o alijamento das classes populares do voto através de exigências tais como o citado letramento:

O espírito das mudanças eleitorais republicanas era o mesmo de 1881, quando foi introduzida a eleição direta. Até esta última data, o processo indireto permitia razoável nível de participação no processo eleitoral, em torno de $10 \%$ da população total. A eleição direta reduziu este número para menos de $1 \%$. Com a República houve aumento pouco significativo para $2 \%$ da população (eleição presidencial de 1894). Percebera-se que, no caso brasileiro, a exigência da alfabetização, introduzida em 1881, era barreira suficiente para impedir a expansão do eleitorado. [...] O liberal Rui Barbosa, um dos redatores do projeto de Constituição de 1891, fora um dos principais propugnadores da reforma de 1881. (CARVALHO, 1987, p.43-44)

Portanto, a perspectiva de que era cara a Olavo Bilac a maciça e efetiva participação política da população comum, pois que a concebia como um dos pilares de sustentação do novo regime democrático brasileiro, traz à tona também um dos grandes dilemas do autor que concentrou muitos de seus esforços justamente na reflexão acerca da possibilidade de criação de maiores vínculos (ou 
de eliminar o "abismo" que existia) entre a República e aquela população brasileira, já que o letramento, exigido pelas próprias leis republicanas e concebido como fundamental pelo cronista para um consciente exercício de cidadania, era talvez um dos serviços que mais faltava às classes populares daqui já bastante e voluntariamente afastadas dos canais oficiais de participação política da época. E complementando este raciocínio, segundo a crônica, era fundamental para Olavo Bilac também o florescimento da República, e o consequente progresso do Brasil, estando no seu ponto de vista ambos ainda bastante condicionados ao cumprimento da urgente tarefa da difusão da instrução primária pelo país, que uma vez realizada, eliminaria o nosso analfabetismo quase que generalizado gerando "criatura[s] livre[s], capaz[es] de defender, transformar esta República" e apagando daquele presente, que se pretendia a

${ }^{9}$ Outras crônicas de Olavo Bilac complementam essa perspectiva que esboçamos e expressam justamente o seu pensamento extremamente crítico acerca do que seria um indivíduo analfabeto no mundo contemporâneo. Fiel defensor das liberdades republicanas, o nosso jornalista também concebia o letramento como condição básica para o pleno e consciente exercício da cidadania em seus diversos matizes e indicava claramente que seriam estes cidadãos letrados ("esclarecidos"), os mais aptos a transformar aquela República ainda bastante jovem, porém em crescimento. Nesse sentido, em crônica da Gazeta de Notícias, na qual Bilac abordava o medo da população carioca em relação ao recenseamento civil proposto pela Prefeitura, supondo-o útil ao alistamento militar, naquele ano de 1906 era afirmado pelo autor que este "povo" não compreendia a fundamental importância do recenseamento para a administração municipal justamente por ser iletrado: "O povo, porém, não compreende isso. Se lhe não demonstrarem cabalmente que o recenseamento civil, organizado pela prefeitura, nada tem de comum com o alistamento militar, organizado pelo Ministério da Guerra, ele, apavorado pelo fantasma 
caminho do moderno sob a égide de uma democracia, os indesejáveis resquícios de nosso passado colonial e escravista. Por outro lado, é notório o fato de que nosso autor ao mesmo tempo em que explicitava a expansão da instrução como fundamental solução para a legitimação, consolidação e aperfeiçoamento da República brasileira, também criticava e apontava o próprio regime vigente como imperfeito e detentor de "tortas" concepções acerca do que realmente seria um sistema de governo republicano-democrático. Revelando-se claramente como desleixado perante a causa da educação popular, e consequentemente com a fundamental "emancipação" da população brasileira, a nossa República ingênua e "desgraçadamente, ainda parece pensar que pode merecer o nome de homem um animal incapaz de decifrar os caracteres do alfabeto...”. (BILAC, 8/1/1905)

A título de ilustração quanto à dimensão e enorme importância dada por nosso autor à massificação da instrução no Brasil, lembramos outra ocasião em que novamente Bilac abordou a problemática da educação, porém mais detalhadamente e em edição do Correio Paulistano de 1908; naquela ocasião Bilac enfocava o "urgente" povoamento do Brasil e que meios o possibilitariam, sendo claro para o autor que "Destes dois problemas sérios e máximos higiene e instrução - está dependendo todo o futuro do Brasil. O

da Farda, há de mais uma vez furtar-se ao cumprimento de um dever social, que tão facilmente e com tão grande utilidade para todos pode ser cumprido. Como , porém, fazer esta demonstração àqueles que, por culpa e desídia do Estado, continuam aviltados pelo analfabetismo, moralmente cegos, tristemente mantidos na ignorância, privados da compreensão dos seus direitos e dos seus deveres?" (BILAC, 17/6/1906) 
povoamento será impossível enquanto não alcançarmos, nestes dois serviços de saneamento e educação, um progresso real que nos honre e glorifique." (BILAC, 12/4/1908) Ou seja, subjacente ao apelo bilaquiano em nome da expansão do saneamento e da massificação da instrução popular estava a sua intepretação de que a concretização de ambas possibilitaria ao povo brasileiro, visto como ainda muito afetado por tais problemas, não somente o seu estabelecimento por todo o território nacional, mas também a sua libertação das moléstias e da ignorância que secularmente lhe afetavam. Assim, os benefícios da efetivação de tais reformas e projetos se dariam não somente em termos de progresso material (por exemplo, na ocupação das áreas supostamente desocupadas de nosso território e das taxas de crescimento demográfico e de expectativa de vida), mas também moral, intelectual e simbólico, já que, como vimos, aos olhos do poeta, principalmente quanto ao analfabetismo, a sua não-resolução definitiva se revelava como altamente nociva à nossa população, pois mantinha esta mesma sob uma condição de inferioridade quase animalesca (BILAC, 8/1/1905), comprometendo assim a sua idealização de uma dia vê-la como plena e finalmente composta por verdadeiros, ativos e patrióticos cidadãos.

De todo modo, é interessante percebermos a oscilação, ou mesmo ambiguidade, presente na perspectiva do cronista Olavo Bilac que ora inclinou-se à interpretação de que a República havia sido um significativo avanço do país em termos político-institucionais ao depor o atrasado e autoritário Império de Pedro II, ora ao entendimento de que aquele mesmo "moderno" regime republicano- 
democrático ainda não representava em termos concretos o que tão ardorosamente desejava para o país naquela virada de século, ou seja, a sua entrada na era de modernidade que se abria, e que certamente não incluía um regime democrático instável politicamente, sem base popular, "sustentado" por constantes fraudes eleitorais, pela ignorância de milhões de analfabetos ou por outros milhares de omissos durante as muitas e despovoadas eleições republicanas. A difícil realidade social, e inevitavelmente política, da República brasileira, como vimos, era claramente enxergada e entendida por nosso poeta-jornalista que chegou a tocar no delicado tema do poder das oligarquias estaduais, dizendo-as impossíveis de serem "arrancadas" do solo brasileiro ${ }^{10}$ e uma das principais causas de nossa fama de "instável democracia" já naquela virada de século. Em certa ocasião, relacionando-se ao programa das festas pan-americanas do ano de 1906, Bilac escreveu ironicamente:

Parece, porém, que alguma coisa faltava no programa... Parece que não bastaria mostrar aos hóspedes, que nos honram com sua visita, a nossa natureza, a nossa eloquência[...]: era preciso mostrar-lhes uma coisa bem nossa, - uma de nossas revoluções.[...] Seria difícil, para completar o programa, organizar uma revoluçãozinha no Rio; e, como a de Mato Grosso já acabou, - os amigos das bernardas

10 Em dado contexto de oposição de grande parte da imprensa ao poder oligárquico, Bilac afirmou: "E, ademais, toda esta oposição é platônica e inútil. Quem é capaz de desenraizar do Ceará, do Amazonas e das Alagoas os Accioly, os Nery e os Malta? Nem um terremoto, nem um cataclismo, nem o Diabo! E, mal que não tem remédio, remediado está." (BILAC, 31/5/1908) 
andavam tristes e cabisbaixos, cochichando uns aos outros: 'Vai ser uma vergonha! vai ser um escândalo! pois, havemos de consentir que todos estes estrangeiros amigos saiam daqui sem ver uma bernarda?' Felizmente, para eles, Sergipe salvou a situação.[...] Precisamos de uma Revolução, para mostrar aos nosso hóspedes o que é esse admirável hábito de nossa Democracia. (BILAC, 12/8/1906)

Contudo, era certo o incômodo de nosso autor com tais "imperfeições" de nossa República que, devido à variedade e extensão de suas mazelas, ainda não havia nos "cativado"; tal "desapego" pelo que levantamos até aqui pode ser atribuído a múltiplas causas e o incômodo de nosso autor em relação a ele chegou a se mostrar mais explicitamente, sobretudo em ocasiões de forte apelo simbólico tal como quando das comemorações do sete de setembro de 1907. Naquele contexto, vinham à tona os explícitos entusiasmo e admiração de Olavo Bilac pelas comemorações de 14 de julho na França então comparadas aos insossos festejos brasileiros para a data de nossa independência política. Em edição da Gazeta de Notícias, ficava bastante evidente a importância que Olavo Bilac dava a expressões patrióticas e adesistas por parte das classes populares à sua pátria bem como o seu lamento por ver aqui justamente o oposto do que constatava naquela França do início do século XX; por outro lado, é importante termos em mente que subjacente à sua comparação que expressava o seu lamento em não ver aqui grandes manifestações de patriotismo, estava fundamentalmente o seu desejo de contar com o apoio popular à ordem republicana aqui constituída e ainda bastante carente deste imprescindível "suporte": 
Sete de Setembro... A bandeira nacional ondula na fachada de cada edifício público. À noite haverá iluminações, e o presidente e os ministros ouvirão no Lírico, o Baile de Máscaras. E mais nada... Nem uma só festa pública, nem uma só demonstração de regozijo popular. O povo sabe que se comemora... ou que deveria comemorar hoje o aniversário da independência do Brasil, - mas fica tão indiferente e tão frio como se se tratasse da independência de qualquer longínqua e insignificante republiqueta. [...] Verificando hoje a nossa frieza, o Sr. Paul Doumer há de lembrar-se com desvanecimento do que são as festas de 14 de julho em Paris: metade da população madrugando em Longchamps para assistir à parada, e as ruas cheias de alegre multidão durante todo o dia[...], e à noite, a imensa metrópole justificando o seu apelido de Ville-Lumière, ardendo e fulgurando [...] na alegria franca dos bailes populares[...] (BILAC, 8/9/1907)

E voltando às primeiras linhas daquela Gazeta de 8 de janeiro de 1905, que descreviam os momentos do golpe de 15 de novembro bem como a aprovação de Olavo Bilac de que se mantivesse a escola que até então funcionava na antiga casa de Deodoro da Fonseca, a partir delas interpretamos que ali estavam muito bem conjugados os caminhos entre os quais oscilou a perspectiva de Olavo Bilac em relação ao regime republicano pelo qual havia militado e que havia testemunhado e experimentado desde o seu nascimento em novembro de 1889. Ali, o seu olhar "misturava" de modo bastante interessante a sua análise crítica de que o regime ainda estava longe dos moldes que idealizara, pois ainda era detentor de inúmeros defeitos a serem "removidos" tal como o seu descaso ante o nosso 
maciço analfabetismo, com as suas impressões bastante autorais, de tom progressista, dramático e laudatório, que ratificavam aquele presente republicano, apesar de sua imperfeição, como parte de um processo extremamente positivo de "edificação" material e moral e que não deveria ser de forma alguma abandonado nem por nossas classes dirigentes e muito menos pelos segmentos sociais populares. Nesse sentido, provavelmente expressando em parte o que Maria Tereza Chavez de Mello afirmou quanto à aproximação do termo "república" em relação a outros, como "futuro" e "progresso", Olavo Bilac, referindo-se a certo processo de edificação, nos sinalizou de modo sintético que a despeito dos problemas vividos pelos brasileiros, a República estava “em construção” e crescente aperfeiçoamento, tanto para os seus partidários como para os “inquilinos que não concorreram com um só tijolo". Era de fundamental importância a persistência nesta "construção" que, embora tivesse perspectiva de maiores resultados apenas num futuro vindouro, já evidenciava naquele início de século uma realidade de suficiente prosperidade para que todos os esforços fossem empenhados na tarefa da consolidação daquela República das oligarquias que ainda atravessaria por muitos avanços e retrocessos ao longo de sua história. Daí, as palavras do jornalista em tom bastante realista, embora esperançoso:

a República já viveu quinze anos, não quero saber se bons ou maus, proveitosos ou inúteis, virtuosos ou criminosos; sei que os viveu, tendo visto morrer uma basta porção dos que a mudaram. A Vida é assim: nós todos vivemos a edificar e a mobiliar casa para os outros; quando as casas ficam prontas, 
entregamos as chaves a inquilinos que não concorreram com um só tijolo para a edificação. (BILAC, 8/1/1905)

Portanto, apesar do extremo valor e apreço que revelou pela ascensão da República no Brasil, Olavo Bilac, no decorrer de sua carreira jornalística, não deixou de lado em sua análise a percepção de que aquele sistema de governo ainda estava um tanto distante de encarnar e realizar em terras brasileiras o que entendia por uma República de fato democrática, garantidora das liberdades civis e políticas mais básicas, em suma, de expressar legitimamente, na esfera da política, aquilo que concebia como progressista e "civilizado". Em se tratando do Brasil, este, a seu ver ainda tinha pela frente um duro caminho de inserção/adaptação ao que considerava como adequado e moderno em termos de uma prática política realmente republicana. Exemplar quanto ao tipo de entraves que o Brasil ainda tinha de superar, ressaltamos dada crônica de Olavo Bilac na famosa revista Kosmos, na qual tornou monarquia e República semelhantes em questões de política, ou mais especificamente, a sua mesma "essência política" era problemática segundo aos olhos de nosso poeta-jornalista. À época, Bilac abordava a criação de projetos de lei que propunham revogar o banimento da família real do Brasil e trazer para o país os despojos mortais do monarca Pedro II e da imperatriz Tereza Cristina. O jornalista entendia os projetos justos e dignos, embora percebesse que ainda pairava entre nossos políticos um ridículo medo de uma possível restauração da monarquia no Brasil. E referindo-se aos nossos políticos ("almas hesitantes e medrosas"), que se esconderam em casa 
como tantos outros cidadãos comuns nos primeiros dias após a Proclamação, bem como a uma suposta "essência da política", nos dizia Olavo Bilac que

Dera-lhes o acaso a República, que nem todas elas haviam pedido, mas que todas elas haviam aceitado, caladas e recolhidas, como convém às almas que não amam os riscos da resistência, nem da adesão entusiástica. Essas pobres almas, uma vez proclamada a República, ficaram dois dias trancadas a sete chaves dentro de uma prudente reserva. Ao terceiro dia, levantaram um cantinho da persiana, e espiaram medrosamente as ruas.[...] Os burgueses trabalhavam; os políticos especulavam; os jornalistas pediam empregos públicos; os poetas sonhavam[...]. Então, desafogadas do medo pânico,[...] foram vivendo e sorrindo, vendo que dos abusos velhos nasciam abusos novos, que, sob formas várias, as paixões eram as mesmas, e que, se o regime havia mudado, não havia mudado a essência da política. (BILAC, 7/1906)

E assim o autor concluía a sua reflexão afirmando que após a ascensão da República não houve a estabilidade política que entendia como fulcral ao florescimento e progresso daquele jovem regime republicano brasileiro, pois,

Desencadearam-se revoltas sobre revoltas, ferveram ambições, entrechocaram-se partidos, fez-se do estado de sítio, um Estado no Estado, puseram-se rebeliões sobre anistias e anistias sobre rebeliões, - e tudo ficou sendo o que era no tempo do Império, e as almas tímidas descansaram... (BILAC, 7/1906) 
Todavia, se para Olavo Bilac a política republicana tinha a mesma "essência" daquela política que sustentou o regime imperial, ainda assim, aos olhos do cronista a República era o único sistema de governo capaz de sanar o que ainda era problemático em nossa realidade social e reformular a identidade do Brasil, de sua população e perante o mundo ocidental. Nesse sentido, eliminar, por exemplo, a "chaga" do analfabetismo, da insalubridade do Rio de Janeiro, dos "maus" hábitos tão presentes na capital, etc., eram tarefas urgentes tanto no plano nacional como internacional, pois "emanciparia" os brasileiros então jogados à ignorância, elevando-os ao status de cidadãos ativos, civilizados e participantes politicamente, eliminaria de vez as corriqueiras caracterizações estrangeiras que representavam o nosso país apenas pela sua imensa beleza natural, insistindo em nos detratar pelos mais diversos motivos, e finalmente possibilitaria a nós o tão desejado lugar junto das nações europeias ditas "modernas" e "civilizadas". Ainda que Império e República supostamente possuíssem "políticas" com a mesma "essência", sob a ótica de Olavo Bilac, a dura realidade nacional da Primeira República era em boa parte fruto da letargia e descaso imperiais diante das mais diversas questões sociais, econômicas e políticas.

Lembramos que é fundamental ter como indubitável a filiação ideológica, filosófica e política do intelectual Olavo Bilac aos ideais de governo republicanos tal como evidenciou desde as crônicas em que rememorou entusiasticamente os acontecimentos da Proclamação até aquelas nas quais deixou claro que a sua "opção" pessoal era pela República-democrática, chegando a revelar-se como "horrendamente 
republicano" (BILAC, 31/3/1907) e a demonstrar enorme apreço pelo basilar momento eleitoral bastante desacreditado pela população brasileira naquele contexto histórico. Por outro lado, digna de nota e inseparável da sua inclinação pelo republicanismo era a sua ótica fundamentalmente crítica a respeito deste mesmo regime republicano que ainda lhe mostrava diversas "arestas" que mereciam urgente "reparo" tais como a sua falta de base popular, a instabilidade política evidente nas disputas intraoligárguicas, a ausência de lisura em seus processos eleitorais, o enorme descaso governamental para com a massificação da instrução primária, o saneamento das grandes cidades e do interior do país, e com a reorganização de nossas forças armadas, dentre outros mais. De qualquer forma, como dissemos, aos olhos de Olavo Bilac a República estava em processo de aperfeiçoamento assim como a nação de brasileiros que estava sob sua "proteção", e nesse sentido, no seu modo de ver, eram fundamentais as contribuições tanto de nossas classes dirigentes, a quem cabia a destacada liderança ${ }^{11}$ neste momento histórico de

${ }^{11}$ Em crônica na qual demonstrava certo lamento pelo regime republicano, então em seu décimo quarto aniversário, Olavo Bilac, mesmo em meio a diversas críticas a nossos políticos, deixava importantes indícios de que entendia que a estes mesmos homens da política nacional cabia a liderança dos rumos do país. Ainda que seu escrito possuísse viés crítico, é interessante perceber que podemos depreender do mesmo que a República ainda estava em pleno processo de constituição e que neste momento fulcral as "rédeas" do país deveriam sim estar nas mãos de nossas elites políticas, afinal, ali estariam elas representadas através de figuras com funções maternais, pedagógicas, mantenedoras, etc. Em suma, naquele o ano de 1903, o mau desenvolvimento regime, aos olhos de Bilac, era responsabilidade de nossos políticos: "Mas a República tem uma puberdade triste e 
realização da modernização social tão necessária ao país, como das classes populares que contribuiriam tanto para a legitimação simbólica do inédito regime, através de sua entusiástica adesão à ordem estabelecida, como para o seu progresso material por meio de sua árdua e valorosa labuta.

\section{Fontes históricas utilizadas:}

BILAC, Olavo. Crônica, Gazeta de Notícias, 2 de agosto de 1903.

BILAC, Olavo. Crônica, Gazeta de Notícias, 15 de novembro de 1903.

BILAC, Olavo. Crônica, Gazeta de Notícias, 6 de novembro de 1904.

BILAC, Olavo. Crônica, Gazeta de Notícias, 8 de janeiro de 1905.

BILAC, Olavo. Crônica, Gazeta de Notícias, 17 de junho de 1906.

BILAC, Olavo. Crônica, Gazeta de Notícias, 12 de agosto de 1906.

BILAC, Olavo. Crônica, Gazeta de Notícias, 31 de março de 1907.

BILAC, Olavo. Crônica, Gazeta de Notícias, 8 de setembro de 1907.

apagada. Dizem alguns que a menina chegou à velhice [...]. Outros, mais otimistas, dizem que a moça está com o desenvolvimento retardado [...]. O certo é que ninguém está satisfeito. A República festeja o seu décimo quarto aniversário no meio de um descontentamento geral. [...] Se ela envelheceu antes da puberdade, ou se, à míngua de nutrição, ainda não tem o desenvolvimento que os seus quatorze anos de vida já lhe deveriam assegurar, - a culpa é vossa, tutores sem escrúpulo, amas-de-leite sem leite, amas-secas sem carinho, educadores sem preparo, mentores sem prudência! Queixai-vos de vós mesmos, e não dela, - que só de vós tem recebido a alimentação do corpo e do espírito. "(BILAC, 15/11/1903) [grifos nossos] 
BILAC, Olavo. Crônica, Gazeta de Notícias, 31 de maio de 1908.

BILAC, Olavo. Crônica, Correio Paulistano, 15 de novembro de 1907.

BILAC, Olavo. Crônica, Correio Paulistano, 12 de abril de 1908.

BILAC, Olavo. Crônica, Correio Paulistano, 15 de maio de 1908.

BILAC, Olavo. Crônica, Kosmos, julho de 1906.

\section{Referências bibliográficas:}

ALONSO, Ângela. Ideias em movimento: a geração de 1870 na crise do Brasil-Império. Rio de Janeiro, Paz e Terra, 2002.

BARBOSA, Marialva Barbosa. Os donos do Rio: imprensa, poder e público. Rio de Janeiro: Vício de Leitura, 2000.

BOURDIEU, Pierre. Campo intelectual e projeto criador. In: Vários, Problemas do estruturalismo, Rio de Janeiro: Zahar, 1968, p. 105-145.

. Os usos sociais da ciência. São Paulo: Editora UNESP, 2004.

CARVALHO, José Murilo de. Os bestializados: o Rio de Janeiro e a república que não foi. São Paulo: Cia das Letras, 1987.

DIMAS, Antônio. Bilac, O Jornalista. São Paulo: Imprensa Oficial do Estado de São Paulo, Edusp, Editora da Unicamp, 2006, 3 v.

ENGEL, Magali Gouveia. Modernidade, dominação e resistência: as relações entre capital e trabalho sob a ótica de João do Rio. Fev. 2004, revisado em abr. 2004, p.22. Disponível em: <http://www.historia.uff.br/tempo/artigos_dossie/artg17-4.pdf> 
- Povo, política e cultura: um diálogo entre intelectuais da Primeira República. Ago. 2006. Disponível em: < http://www.rj.anpuh.org/resources/rj/Anais/2006/conferencias/ Magali\%20Gouveia\%20Engel.pdf> . Os intelectuais e a Liga de Defesa Nacional: por um projeto hegemônico de Brasil. V Simpósio Nacional Estado e Poder: Hegemonia. Out. 2008. Disponível em: $<$ http://www.simposiohegemonia.pro.br/05_Engel_Magali_Gou veia.pdf $>$.

. A Liga de Defesa Nacional como partido: os intelectuais e a

construção da hegemonia burguesa. Janeiro - março de 2010, vol. 8, p. 318.

<http://www.iealc.fsoc.uba.ar/hemeroteca/elatina30.pdf >

LESSA, Renato. A invenção da República no Brasil: da aventura à rotina. In: CARVAlHO, Maria Alice Rezende de. (Org.) A República no Catete, Rio de Janeiro: Museu da República, 2001, p.11-58.

MELlO, Maria Tereza Chaves de. A República Consentida, Rio de Janeiro: Editora FGV, 2007.

. A Modernidade Republicana. Revista Tempo, Niterói: 2008, nº 26.

Disponível

em:

$<$ http://www.historia.uff.br/tempo/artigos_dossie/v13n26a02.pd $\underline{f}>$

. A República e o Sonho. Revista Varia Historia, Belo Horizonte: 2011, vol. 27, $\mathrm{n}^{\mathrm{o}}$ 45. Disponível em: 
$<$ http://www.scielo.br/scielo.php?pid=S01048775201100010000 6\&script=sci_arttext>

OLIVEIRA, Lúcia Lippi. A questão nacional na Primeira República. São Paulo: Brasiliense, 1990.

JÚNIOR, Álvaro Santos Simões. A Sátira do Parnaso. São Paulo: Ed. UNESP, 2007.

SILVA, Maurício. A Academia Brasileira de Letras e a institucionalização do academicismo no Brasil do final do século XIX. O eixo e a roda, vol. $\quad 14,2007 . \quad$ Disponível em $<$ http://www.letras.ufmg.br/poslit/08_publicacoes_pgs/Eixo\%20 e\%20a\%20Roda\%2014/04-Mauricio-Silva.pdf>

SODRÉ, Nelson Werneck. A História da imprensa no Brasil. Rio de Janeiro: Civilização Brasileira, 1966. 